\title{
Non-Enzymatic Selective Detection of Glucose Based on a Gold Nanoparticle- Carbon Nanotube Composite Film
}

\author{
David Branagan $^{\mathrm{a}}$ and Carmel B. Breslin ${ }^{\mathrm{b}}$ \\ ${ }^{\mathrm{a}, \mathrm{b}}$ Department of Chemistry, National University of Ireland Maynooth, County Kildare, \\ Ireland
}

A gold nanoparticle-functionalised multi-walled carbon nanotube composite, fMWCNT- $\mathrm{Au}_{\text {nano, }}$, was prepared by a simple reduction method using sodium borohydride and was used for sensing glucose non-enzymatically at neutral $\mathrm{pH}$. The morphology and composition of the fMWCNT-Au $\mathrm{An}_{\text {nano }}$ hybrid were characterised by TEM, EDX and AA. TEM analysis indicated the gold nanoparticles to be mainly under $10 \mathrm{~nm}$ in size and both EDX and AA quantified the gold loading at $2 \%$ weight of composite. Constant potential amperometry was used for electrochemical detection of glucose and Nafion ${ }^{\circledR}$ membranes were employed to reduce interference from the commonly occurring AA and UA interferants, present in blood at high concentrations.

\section{Introduction}

Diabetes is a major world health problem that affects $6.4 \%$ of the world's adult population. By 2030, its prevalence is expected to rise to $7.7 \%$ (1). Moreover, significant risks are associated with this metabolic disorder, including renal, eye and cardiovascular damage and it can also result in stroke, peripheral vascular disease and amputation (2). Therefore, the quantification of blood glucose levels has become very important. Many enzymatic sensors are present for this purpose, but due to their biological nature a number of problems can exist, with stability and inaccurate glucose sensing being the most serious. Enzymes used in these sensors exhibit degradation with $\mathrm{pH}$, temperature and humidity changes (3). To possibly overcome these issues, interest in non-enzymatic sensors has gained much attention, as eliminating the use of enzymes could offer a more stable and accurate glucose detection (3).

Certain metals, namely $\mathrm{Au}(4-6), \mathrm{Pt}(7,8)$ and $\mathrm{Cu}(9,10)$ in nano or microstructured forms have proven to be very effective for non-enzymatic glucose sensing, yet those that utilise $\mathrm{Cu}$ are only applicable at higher $\mathrm{pH}$, in $\mathrm{NaOH}$. Au and $\mathrm{Pt}$ are both capable of glucose detection at neutral $\mathrm{pH}$, but with Au displaying higher electroactivity towards glucose oxidation than $\mathrm{Pt}(11)$.

Carbon nanotubes are popularly used in electrochemical systems and are known to exhibit a range of impressive structural and physical properties, such as large surface area, high conductivity, chemical stability and modifiable surfaces (12). Sensors combining both metal nanoparticles and carbon nanotubes have been fabricated and examples of metals used include, $\mathrm{Au}(13-15), \mathrm{Pt}(16,17), \mathrm{Cu}(18,19)$ and $\mathrm{CuO}(20,21)$. However, many of the procedures are complicated with several steps and the non-enzymatic 
glucose sensors generally have glucose-sensing restrictions to alkaline solutions (22). Herein we report a simple, synthetic deposition of Au nanoparticles onto functionalised multi-walled carbon nanotubes for use in a sensor capable of measuring physiological concentrations of glucose at blood $\mathrm{pH}$. Moreover, interference from two common molecules, ascorbic acid and uric acid, is effectively eliminated in physiological ranges by use of an anion-rejecting permselective Nafion ${ }^{\circledR}$ membrane (23). The fMWCNT$\mathrm{Au}_{\text {nano }}$ composite was characterised by Transmission Electron Microscopy, TEM, Energy Dispersive X-Ray Spectroscopy, EDX, and Atomic Absorption Spectroscopy, AAS.

\section{Experimental}

$\underline{\text { Instruments and Chemicals }}$

Cyclic voltammetry was carried out using a Solartron SI 1287 potentiostat and amperometry using a $\mathrm{CH}$ Instruments $\mathrm{CHI} 760 \mathrm{C}$ potentiostat with a conventional three electrode cell consisting of a glassy carbon, GC, working electrode of $3 \mathrm{~mm}$ diameter, a high surface area platinum counter electrode and a saturated calomel references electrode, SCE. TEM work was carried out using a FEI Titan TEM, EDX using an Oxford Instrument INCAx-act EDX system attached to a Hitachi S-3200-N Scanning Electron Microscope and AA using a Perkin Elmer Precisely AAnalyst system. All chemicals used were of high purity and were purchased from Sigma Aldrich. Experiments were conducted at room temperature.

\section{Synthesis of Composite}

Pristine MWCNTs were refluxed in concentrated $\mathrm{HNO}_{3}$ to produce carboxylated MWCNTs (24), termed 'fMWCNTs'. To a $0.5 \mathrm{mg} / \mathrm{ml}$ dispersion of these fMWCNTs, in $20 \mathrm{mls}$ of SDS surfactant, volumes of $600 \mu \mathrm{l}$ of $1 \% \mathrm{w} / \mathrm{v} \mathrm{HAuCl}_{4}$ solution and $600 \mu \mathrm{l}$ of $0.75 \% \mathrm{w} / \mathrm{v} \mathrm{NaBH}_{4}$, were added successively. This was completed under magnetic stirring and left for $5 \mathrm{~min}$. Product was then isolated on a $0.45 \mu \mathrm{m}$ Whatman ${ }^{\circledR}$ membrane and washed with copious amounts of Millipore ${ }^{\circledR}$ water. The obtained composite, termed

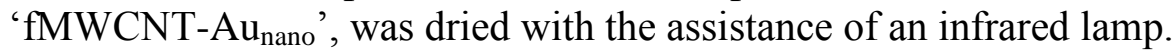

\section{$\underline{\text { Modification of Electrode }}$}

For casting onto the electrode surface, the composite was re-solublised in SDS surfactant and drop cast onto a $3 \mathrm{~mm} \mathrm{GC}$ electrode. This electrode had been previously polished with $0.5 \mu \mathrm{m}$ aluminium oxide paste and cleaned in an ethanol-water mixture by ultrasonication. The prepared electrode was then left under an IR lamp until completely dry. To improve selectivity, Nafion ${ }^{\circledR}$ membranes were produced, from a Nafion ${ }^{\circledR} 118$ solution, but were added after the electrochemical pre-treatment step, discussed below.

\section{Electrochemical Parameters and Glucose Detection}

Before the electrochemical sensing of glucose, an electrochemical pre-treatment in $\mathrm{NaOH}$ solution, using cyclic voltammetry between the potentials of $-0.4 \mathrm{~V}$ and $0.6 \mathrm{~V}$ vs. SCE and at a scan rate of $100 \mathrm{mVs}^{-1}$ was utilised to remove the adsorbed SDS from the composite film. The sensor was then cycled using the same window in the background 
electrolyte of $0.1 \mathrm{M}$ PBS at $\mathrm{pH} 7.4$ to remove $\mathrm{NaOH}$ and to obtain a steady-state background response. Glucose detection was undertaken using constant potential amperometry, CPA, at $0.3 \mathrm{~V}$ vs. SCE. Prior to the addition of glucose, the composite film remained in the background electrolyte with the applied potential of $0.3 \mathrm{~V}$ vs. SCE until a steady-state current response was obtained.

\section{Results and Discussion}

\section{Characterisation of the Composite}

High-resolution TEM, HRTEM, was used to visualise the gold nanoparticles, GNPs, on carbon nanotube, fMWCNT, surfaces. It can be seen in the micrographs presented in Figure 1 that the GNPs are not homogenously covering the fMWCNTs, but at least are nanoparticulate and mainly under $10 \mathrm{~nm}$.
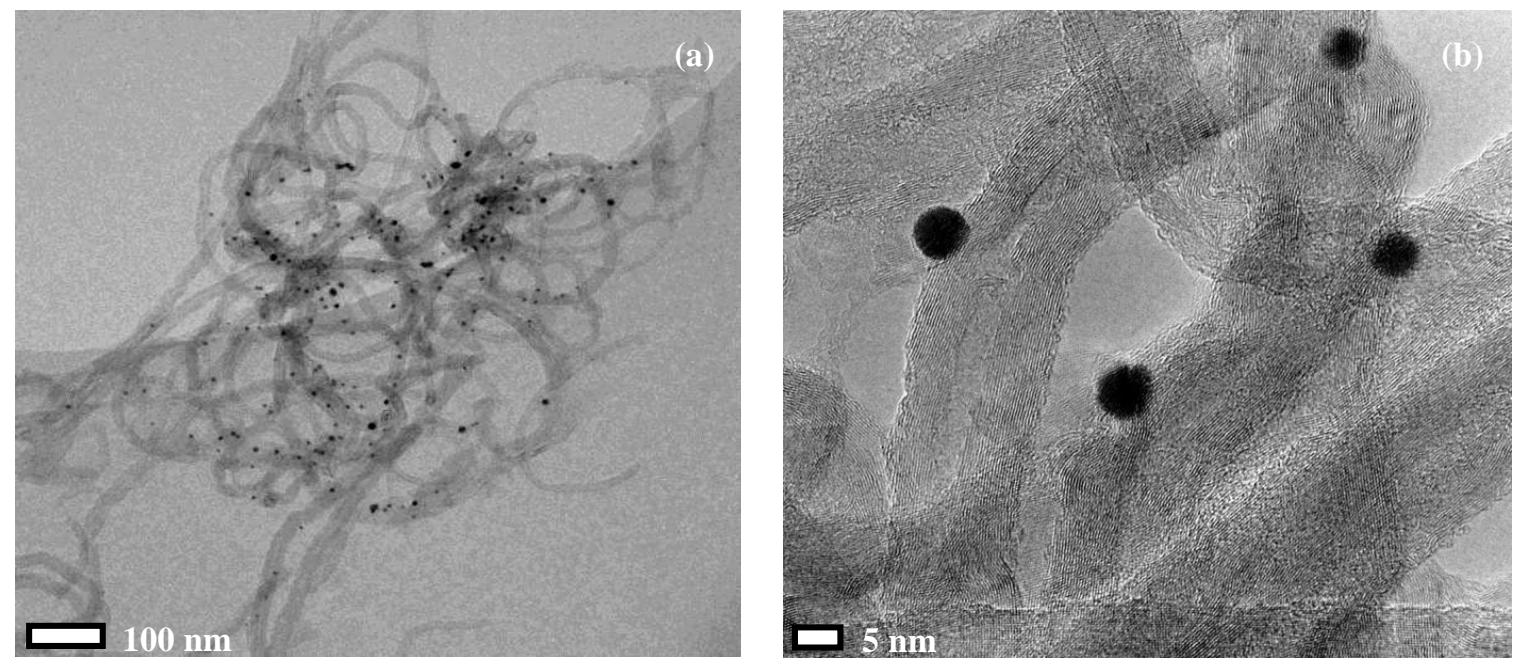

Figure 1.TEM micrographs of the fMWCNT-Au $\mathrm{unn}_{\text {nan }}$ composite at (a) low and (a) high magnifications.

The presence of gold in the composite was confirmed using Energy Dispersive X-Ray Spectroscopy, EDX. A typical spectrum is shown in Figure 2. Although EDX is not a quantitative technique, it was used to estimate the gold loading. It was estimated from EDX that the gold was present at $2.86 \%$ wt. of composite sample. Atomic Absorption Spectroscopy, AAS, quantified the gold composition as $2.00 \%$ wt., which is very similar to that estimated by EDX. 


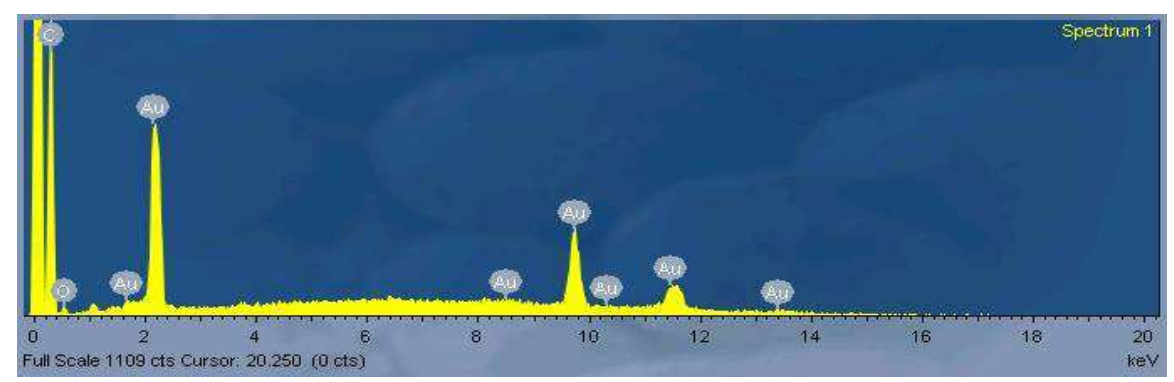

Figure 2. EDX spectrum of fMWCNT-Aunano composite.

\section{$\underline{\text { Glucose Detection }}$}

Glucose detection at the fMWCNT-Aunano and fMWCNT-Au nano $_{\text {nafion }}{ }^{\circledR}$ composite films were achieved using Constant Potential Amperometry, CPA, and results from the fMWCNT-Aunano film is shown in Figure 3. The current responses correspond to the successive additions of a stock glucose solution made in PBS. Various potentials were employed but it was found that $0.3 \mathrm{~V}$ vs. SCE provided the optimum results.

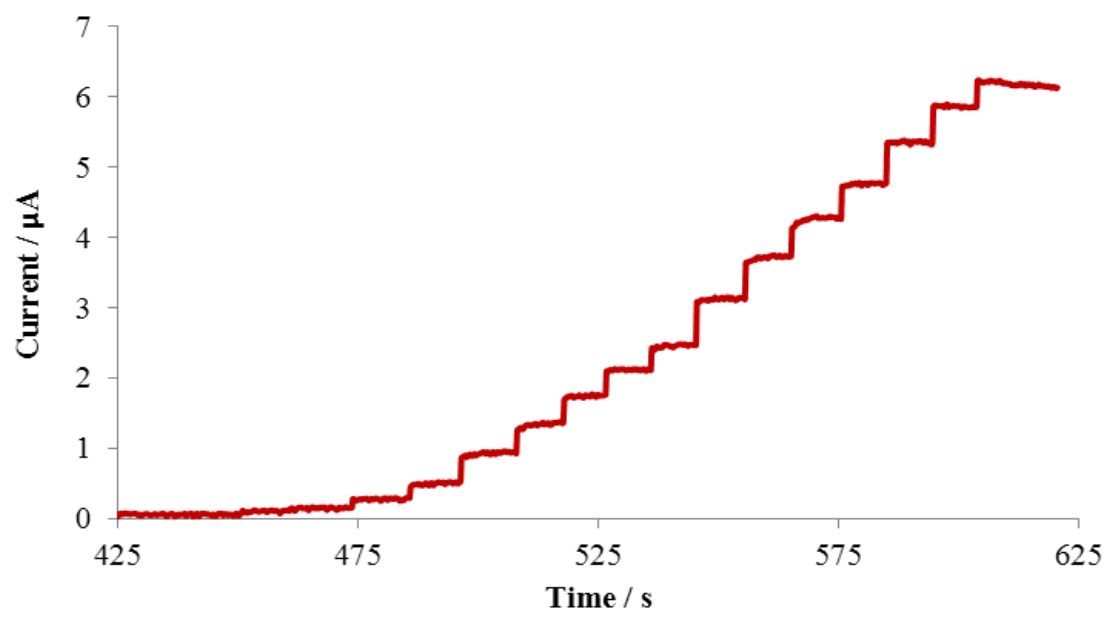

Figure 3. Current time plot for the oxidation of glucose in $0.1 \mathrm{M}$ PBS at the $\mathrm{NaOH}$ pretreated fMWCNT-Au $\mathrm{An}_{\text {nano }}$ composite film. Applied potential of $0.3 \mathrm{~V}$ vs. SCE.

These data were used to generate calibration curves, shown in Figure 4. Slope values were obtained from these plots and used as sensitivity values. These sensitivities were $0.349 \mu \mathrm{A} / \mathrm{mM}$ and $0.073 \mu \mathrm{A} / \mathrm{mM}$ for the fMWCNT- $\mathrm{Au}_{\text {nano }}$ and fMWCNT-Au $\mathrm{Anno}_{\mathrm{n}} / \mathrm{Nafion}{ }^{\circledR}$ composite films, respectively. Limits of detection for glucose at these films were also calculated from the plots, with values of $0.098 \mathrm{mM}$ and $0.817 \mathrm{mM}$ corresponding to the fMWCNT-Au ${ }_{\text {nano }}$ and fMWCNT-Au ${ }_{\text {nano }} / \mathrm{Nafion}^{\circledR}{ }^{\circledR}$ composite films, respectively. With the addition of a Nafion ${ }^{\circledR}$ membrane, improved selectivity was achieved, although the sensitivity was decreased significantly and the limit of detection for glucose increased. As shown in Figure 4, for the calibration plots of glucose detection at both of these sensing films, the Nafion ${ }^{\circledR}$-containing composite clearly gives a reduced sensitivity, most probably due to the increase in the diffusion layer. 


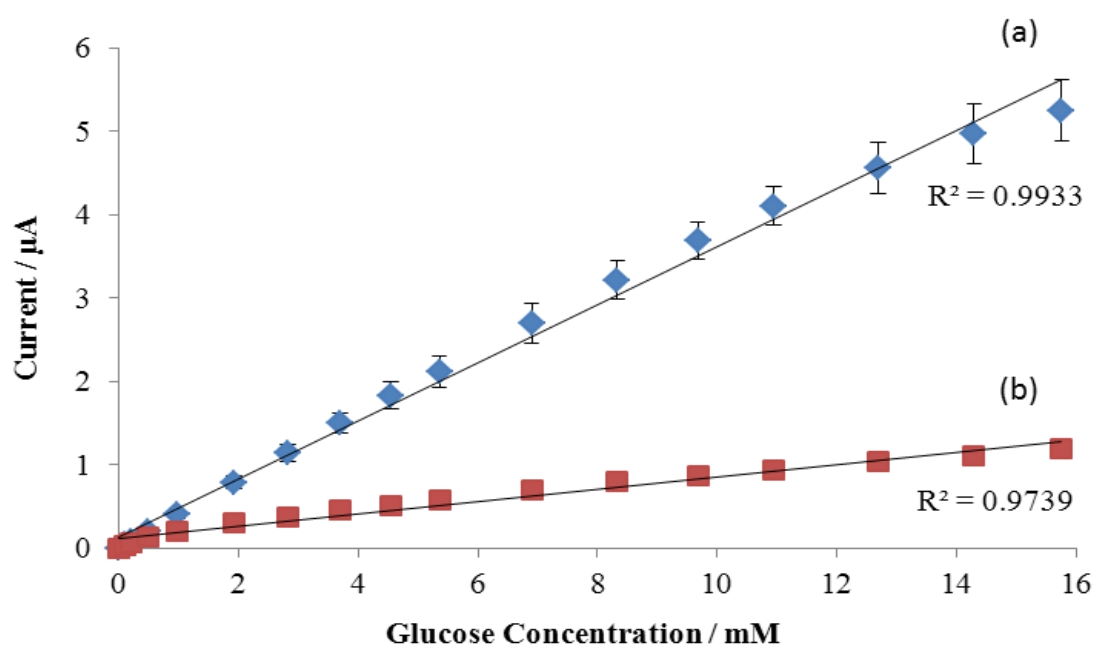

Figure 4. Plots of current responses for the oxidation of glucose in $0.1 \mathrm{M} P B S$ at $\mathrm{NaOH}$ pre-treated (a) fMWCNT-Au ${ }_{\text {nano }}$ and (b) fMWCNT-Aunano $/$ Nafion ${ }^{\circledR}$ composite films. $n$ $=3$.

\section{$\underline{\text { Interferants }}$}

Ascorbic acid, AA, proved to be a significant interferant at the fMWCNT-Aunano composite film without the selective Nafion ${ }^{\circledR}$ membrane, as seen in Figure 5 (a). The maximum physiological level of $0.1 \mathrm{mM}$ AA (25) resulted in a large current response which meant a permselective Nafion ${ }^{\circledR}$ membrane had to be used. With the addition of this membrane, interference from physiological levels of AA was effectively eliminated and the interference from higher concentrations of AA was reduced significantly, as seen in Figure 5 (b).
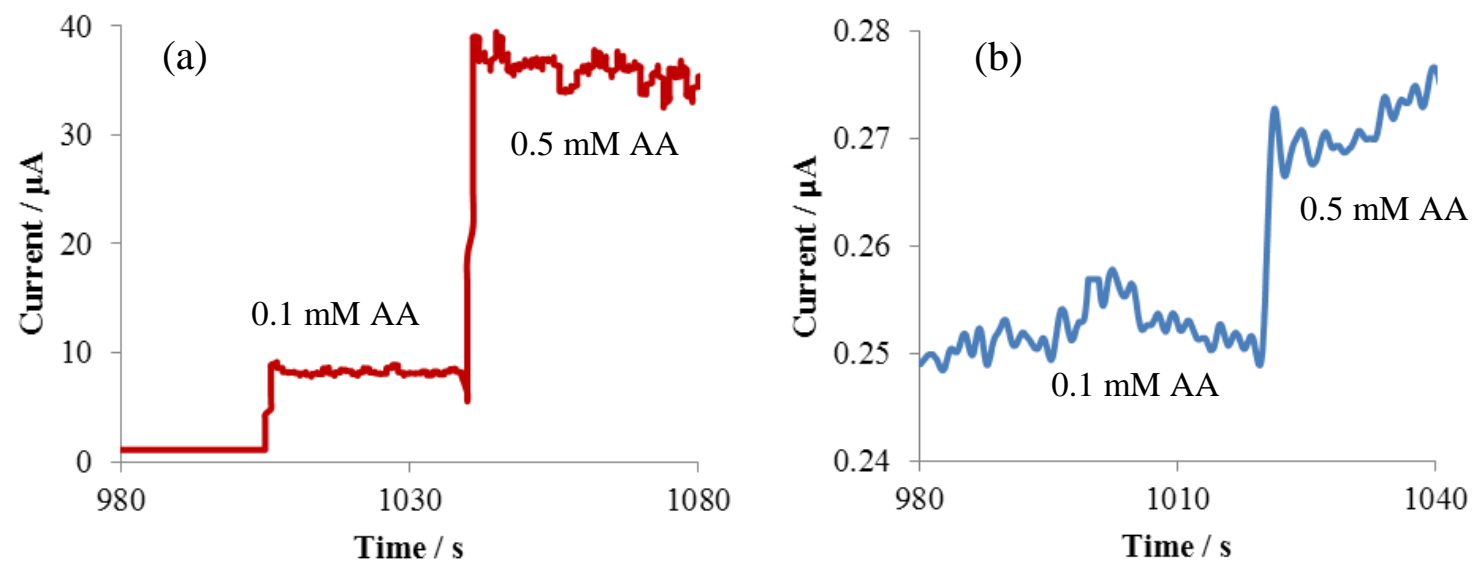

Figure 5. Current time plots for the oxidation of ascorbic acid in $0.1 \mathrm{M}$ PBS at the $\mathrm{NaOH}$ pre-treated (a) fMWCNT-Au nano $_{\text {and (b) } \text { fMWCNT-Aunano } \text { Nafion }}{ }^{\circledR}$ composite film. Applied potential of $0.3 \mathrm{~V}$ vs. SCE. 
Uric acid, UA, being a substance existing at high physiological concentrations was also expected to provide interference at the composite films. In the case of UA, different concentrations exist for males and females, with about $0.20-0.42 \mathrm{mM}$ being the normal physiological range for males and a lower range of $0.14 \mathrm{mM}-0.35 \mathrm{mM}$ being normal for females (26). Higher levels above these ranges, for both males and females, were investigated at the composite film without and with the Nafion ${ }^{\circledR}$ membrane. Representative data are shown in Figure 6 (a) and (b) for the fMWCNT-Aunano and for the fMWCNT-Au nano $/ \mathrm{Nafion}^{\circledR}$ film, respectively. It is clear that UA posed problems due to the large current responses, but again this interference was significantly reduced with the permselective membrane, by over $99 \%$.
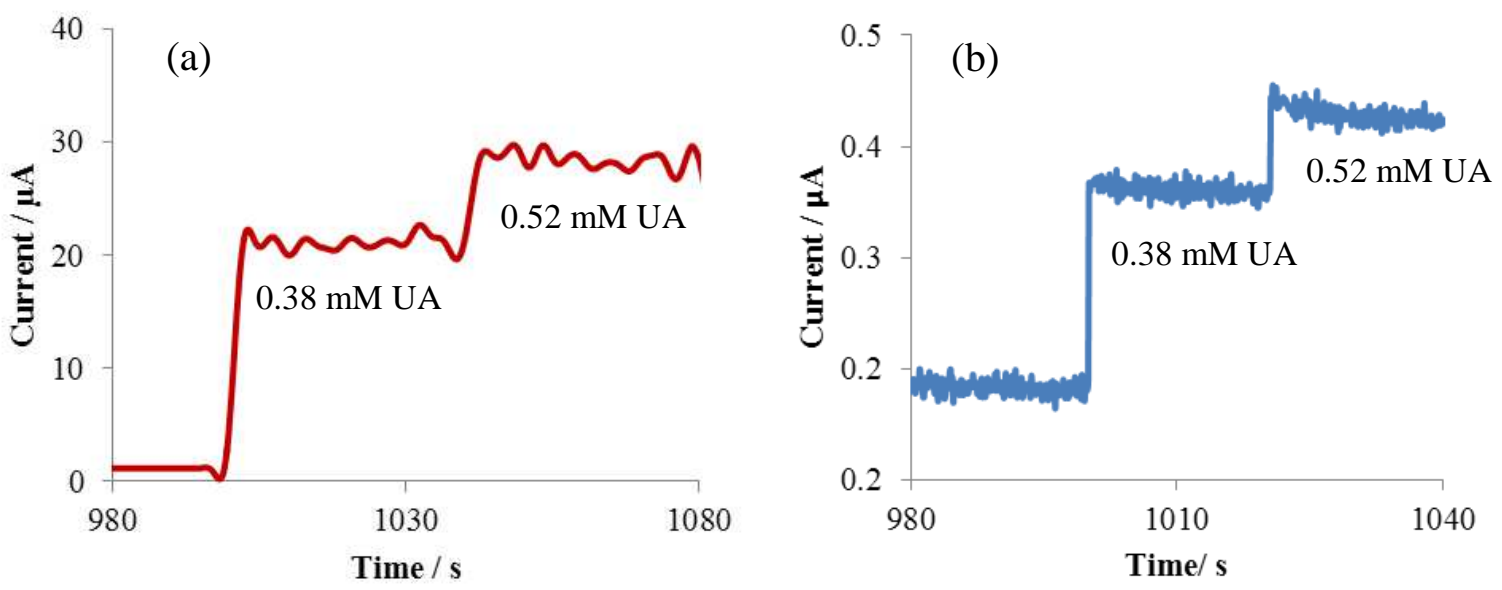

Figure 6. Current time plots for the oxidation of uric acid in $0.1 \mathrm{M}$ PBS at the $\mathrm{NaOH}$ pretreated (a) fMWCNT-Au $u_{\text {nano }}$ and (b) fMWCNT-Au nano $/ \mathrm{Nafion}^{\circledR}{ }^{\circledR}$ composite film. Applied potential of $0.3 \mathrm{~V}$ vs. SCE.

\section{Conclusion}

Gold nanoparticles of less than $10 \mathrm{~nm}$ were successfully formed on the surface of functionalised multi-walled carbon nanotubes by chemical reduction with sodium borohydride, to form a composite termed fMWCNT-Aunano. This composite consisted of gold at $2 \% \mathrm{wt}$. and when cast onto GC electrodes proved useful for non-enzymatic glucose sensing at neutral $\mathrm{pH}$. This film was also capable of detecting the common interferants, AA and UA, which proved to be an issue, although this was essentially eliminated using a permselective Nafion ${ }^{\circledR}$ membrane. Other than reducing the extent of interference, this membrane also decreased the films sensitivity towards glucose. Future work will be carried out to increase sensitivity and selectivity towards glucose and also to miniaturise this system on screen-printed electrodes.

\section{References}

1. J. E. Shaw, R. A. Sicree and P. Z. Zimmet, Diabetes Research and Clinical Practice, 87, 4, (2010).

2. A. D. Deshpande, M. Harris-Hayes and M. Schootman, Physical Therapy, 88, 1254, (2008). 
3. S. Park, H. Boo and T. D. Chung, Analytica Chimica Acta, 556, 46, (2006).

4. L. Y. Chen, X. Y. Lang, T. Fujita and M. W. Chen, Scripta Materialia, 65, 17, (2011).

5. Y. Xia, W. Huang, J. Zheng, Z. Niu and Z. Li, Biosensors and Bioelectronics, 26, 3555, (2011).

6. Y. Li, Y.-Y. Song, C. Yang and X.-H. Xia, Electrochemistry Communications,9, 98, (2007).

7. J. Segyeong, P. Sejin, D. Taek, Chung and C. Hee, Kim, Analytical Sciences, 23, 227, (2007).

8. S. H. Kim, J. B. Choi, Q. N. Nguyen, J. M. Lee, S. Park, T. D. Chung and J. Y. Byun, Physical Chemistry Chemical Physics, 15, 5782, (2013).

9. S. Sattayasamitsathit, P. Thavarungkul, C. Thammakhet, W. Limbut, A. Numnuam, C. Buranachai and P. Kanatharana, Electroanalysis, 21, 2371, (2009).

10.B. Qi, H. Yang, K. Zhao, M. M. Bah, X. Bo and L. Guo, Journal of Electroanalytical Chemistry, 700, 24, (2013).

11.K. E. Toghill and a. R. G. Compton, International Journal of Electrochemical Science, 5, 1246, (2010).

12.A. Merkoçi, M. Pumera, X. Llopis, B. Pérez, M. del Valle and S. Alegret, $\operatorname{Tr} A C$ Trends in Analytical Chemistry, 24, 826, (2005).

13.H. Zhu, X. Lu, M. Li, Y. Shao and Z. Zhu, Talanta , 79, 1446, (2009).

14.Y. S. Kim, A. Cha, J. Y. Shin, H. J. Jeon, J. H. Shim, C. Lee and S.-g. Lee, Chemical Communications, 48, 8940, (2012).

15.H. Ismaili, F. Lagugné-Labarthet and M. S. Workentin, Chemistry of Materials, 23, 1519, (2011).

16.L.-H. Li and W.-D. Zhang, Microchimica Acta, 163, 305 (2008).

17.D. Rathod, C. Dickinson, D. Egan and E. Dempsey, Sensors and Actuators B: Chemical, 143, 54, (2010).

18.L.-M. Lu, X.-B. Zhang, G.-L. Shen and R.-Q. Yu, Analytica Chimica Acta, 715, 99, (2012).

19. X. Kang, Z. Mai, X. Zou, P. Cai and J. Mo, Analytical Biochemistry, 363, 143, (2007).

20.L.-C. Jiang and W.-D. Zhang, Biosensors and Bioelectronics, 25, 1402, (2010).

21.Z. Asadbeigi, A. A. Khodadadi, M. Afsharpour, Y. Mortazavi and M. VesaliNaseh, IMCS 2012 - The 14th International Meeting on Chemical Sensors, 866 (2012).

22. Z. Zhigang, G.-G. Luis, J. F. Andrew, X. Huaqing, M. Francis and I. M. William, Sensor, 12, 5996, (2012).

23. H. Dai, X. Wu, H. Xu, M. Wei, Y. Wang and G. Chen, Electrochemistry Communications, 11, 1599 (2009).

24. I. D. Rosca, F. Watari, M. Uo and T. Akasaka, Carbon, 43, 3124, (2005).

25. M. D. Rubianes and G. A. Rivas, Electrochemistry Communications, 5, 689, (2003).

26. A. N. Dhinaa and P. K. Palanisamy, Natural Science, 2, 106, (2010). 